\title{
Self-concept, self-esteem and academic achievement: strategies for maintaining self-esteem in students experiencing academic failure
}

\author{
Francisco Peixoto • Leandro S. Almeida
}

Received: 20 February 2008 /Revised: 21 September 2009 /Published online: 25 February 2010

(C) Instituto Superior de Psicologia Aplicada, Lisboa, Portugal and Springer Science+Business Media BV 2010

\begin{abstract}
Previous research into the relationship between self-esteem and academic achievement shows that despite differences in academic self-evaluation, students' global self-representations do not differ as a result of their grades at school. In this study, we will analyse the strategies that underachievers used to maintain their self-esteem at an acceptable level. The participants were 955 adolescents in the 7 th, 9th and 11th grades at four secondary schools in Lisbon. Three hundred fifty-two of these students had retaken a year at least once in their school careers, whilst 603 had never done so. We collected the data using both a self-concept scale and a scale for evaluating attitudes towards school. Results show that self-esteem is maintained through positive self-representations in non-academic facets of self-concept and/or by devaluing school-related competences. They also show that younger students are less likely to maintain self-esteem by devaluing the school experience.
\end{abstract}

Résumé Les travaux de recherche sur la relation entre l'estime de soi et les résultats scolaires montrent que les élèves ayant réussite scolaire ne présentent pas des autoreprésentations globales plus positives que les élèves en situation d'échec, malgré le fait que leurs autoreprésentations académiques soient différentes. Dans cette étude nous avons analysé les stratégies que les élèves en situation d'échec scolaire utilisent pour maintenir l'estime de soi dans des niveaux acceptables. Dans cette recherche ont participé 955 adolescents du 7ème, 9 ème et 11 ème années de scolarité, de quatre écoles d'enseignement secondaire de Lisbonne. De ceux ci, 352 ont redoublé au moins une fois dans leur passée scolaire, tandis que 603 n'ont jamais redoublé. Pour recueillir les données nous avons utilisé une échèle pour évaluer le concept de soi et une autre pour évaluer les attitudes par rapport à l'école. Les résultats montrent que les élèves maintiennent leur estime de soi à travers des autoreprésentations positives dans

\footnotetext{
F. Peixoto $(\bowtie)$

Instituto Superior de Psicologia Aplicada, R. Jardim do Tabaco, 34, 1149-041 Lisbon, Portugal e-mail: fpeixoto@ispa.pt

\section{S. Almeida $(\bowtie)$}

Instituto de Educação e Psicologia, Universidade do Minho, Campus de Gualtar, 4710-057 Braga, Portugal

e-mail: leandro@iep.uminho.pt
} 
des domaines non-académiques du concept de soi et/ou à travers la dévalorisation des compétences associés à l'école. Les résultats mettent, aussi, en évidence que chez les élèves plus jeunes l'estime de soi n'est pas maintenue à travers des stratégies qui font appel à une dévalorisation de l'expérience scolaire.

Keywords Self-esteem $\cdot$ Self-concept $\cdot$ Academic achievement

\section{Introduction}

Self-representations (self-concept or self-esteem) are usually associated with a wide range of performance indicators (Jackson et al. 2001; Judge et al. 1998; Peixoto 2003). In an academic context, self-representations are positively associated with academic achievement, motivation and attitudes towards school (Choi 2005; Marsh and Craven 2005; Valentine and DuBois 2005); however, it is important to make a distinction between global selfrepresentations, such as global self-concept or self-esteem, and specific representations, such as academic self-concept or mathematical self-concept (Harter 1999). For example, the magnitude of the relationship between academic achievement and self-representations differs depending on the level of specificity one adopts. Stronger relationships have been found with the academic self-concept than with self-esteem (Hoge et al. 1995; Lyon 1993; Marsh 1987; Muijs 1997; Skaalvik and Hagtvet 1990). Low correlation coefficients between self-esteem and academic achievement can be explained in different ways. For example, when a student exhibits low academic achievement, this does not necessarily imply feelings of personal devaluation. On the other hand, positive self-esteem is a more global perception and influenced by all the daily domains of performance (Branscombe and Wann 1994; Covington 1984; Leary et al. 1995), and sometimes a low academic selfconcept can activate mechanisms which will protect self-esteem.

One explanation for the need to protect self-esteem can be found in social identity theory where, when a person's social identity is under threat, as a member of a group, he/she has various options. One involves social mobility - i.e. leaving his/her group of origin and joining another one that enables him/her to regain a positive social identity (Tajfel 1983; Wetherell 1996). Another way is to become "socially creative" by reinterpreting the threatening situation in such a way that unfavourable comparisons cease to be unfavourable. This reinterpretation of the situation can entail changing comparison group (i.e. comparing oneself to groups with poorer performances in the dimensions concerned), finding alternative dimensions that permit favourable comparisons or inverting the values of the characteristics that gave rise to unfavourable comparisons (Robinson and Tayler 1986; Wetherell 1996).

Robinson and colleagues (Robinson 1978; Robinson and Breslav 1996; Robinson and Tayler 1986, 1991; Robinson et al. 1990) based their study on the social identity theory in order to explain students' academic failure and lack of motivation. In their opinion, the first identity protection strategy-social mobility-is unavailable to the majority of students who experience academic failure because most of them find it difficult to become successful. They are thus left with the options of becoming "socially creative" and inverting the value of the critical dimension in such a way as to make failure a source of satisfaction, or finding alternative dimensions in relation to which comparisons with other groups permit a positive differentiation, or both these strategies at once (Robinson and Tayler 1986). In extreme cases, students can organise themselves on the basis of an anti-institutional culture which precisely values "being bad" at school and/or the display of behaviours that are characteristic of adult status (drinking alcohol, smoking, having sex, etc.), most notably in 
adolescence when the peer group plays a predominant role in interpersonal relationships (Robinson and Tayler 1986, 1991; Senos 1997).

Some of the work that has been done within this theoretical framework has shown the absence of differences in global self-esteem (despite proven differences in academic selfconcept) or of an increase in negative attitudes towards school among students who experience academic failure (Robinson and Tayler 1986, 1991; Senos 1997). However, the development of more negative attitudes towards school does seem to be supported and encouraged by group dynamics (Senos 1997).

Other researchers emphasise the variables which mediate the relationship between selfesteem and school results. Kaplan and colleagues (Kaplan 1982; Kaplan and Lin 2000; Kaplan et al. 1994; Liu et al. 1992) assume that one of the ways to deal with academic failure can entail devaluing its source — i.e. school—so as to make it possible to maintain a positive self-esteem. In a study involving 242 adolescents between the 7 th and 12 th grades, Liu et al. (1992) obtained results that support a model in which self-esteem indirectly affects academic achievement via its influence on the occurrence of deviant behaviours and on motivation. In turn, school classifications indirectly affect self-esteem via academic selfconcept. Results of a longitudinal study involving 1,756 adolescents (Kaplan et al. 1994) confirm the existence of a relationship between self-esteem and school results, which is mediated by willingness to deviate from the prevailing rules.

However, other studies by Robinson and colleagues (Robinson and Breslav 1996; Robinson and Tayler 1991) arrive at different conclusions. In a study with 150 students from three different countries (England, France and Japan), Robinson and Tayler (1991) show that students who are underachieving display lower levels of self-esteem. Robinson and Breslav (1996) obtained similar results with a sample of 504 Lithuanian adolescents. In both studies, the students who achieved the least also exhibited low scores in a number of school-related variables, thereby reflecting a low level of commitment to academic life. These results led Robinson and Breslav (1996) to claim that the reconstruction of a threatened social identity probably only occurs in extreme social contexts in which the social structure facilitates categorisation - i.e. when belonging to the "bad student" category is concurrent with belonging to a clearly identifiable social group (based on differences in ethnicity, social class or other factors).

A study by Osborne (1995) offers results that provide a degree of support for the thesis put forward by Robinson and Breslav (1996). In an attempt to explain the seemingly paradoxical results of comparative studies which found that among students the self-esteem of African Americans was the same as or greater than that of Americans with European origins, Osborne suggests the hypothesis of a reduction in the identification with school. His thesis is that American cultural stereotypes attribute inferior intellectual abilities to African Americans and that this can be seen as a threat to the self-esteem of African American students. At the same time, poor performance at school can reinforce this threat inasmuch as it strengthens the negative stigma of the racial stereotype. His explanation for the fact that despite this negative picture African American students display positive levels of self-esteem is rooted in the assumption that they decrease their investment in school and thus construct their self-esteem independent of academic performance. For example, data from a longitudinal study involving 12,000 students (1,233 African Americans and 10,767 Caucasians) who were assessed in the 8th and 10th grades revealed differences in the academic achievement of the two groups, absence of differences in their self-esteem and a lower correlation between self-esteem and school results for African American students (Osborne 1995).

As Harter (1993, 1998, 1999) suggests, two further possibilities for a subject to maintain self-esteem at acceptable levels entail reorganising self-concept in such a way as to decrease 
investment in areas that constitute a threat to his/her self-esteem and attach less importance to them, or else to increase his/her levels of competence in those areas. Both strategies seek to reduce the discrepancy between that which the person wants to be and that which he/she thinks he/she is (perceived competence). So, in Harter's model, self-esteem depends on the distance between perceived competence and the importance attributed to the different dimensions of selfconcept, which has a degree of affinity with social identity theory (Robinson and Breslav 1996; Robinson and Tayler 1986, 1991; Robinson et al. 1990). Despite the individual emphasis on the strategies for maintaining self-esteem, Harter (1993) considers that in certain facets of selfconcept - particularly the school-related dimensions - it is difficult for individuals to attach less importance to those facets because of social pressure in the opposite direction.

Combining the Robinson and Harter models, a study with 613 Portuguese students from the seventh to the ninth grades (Peixoto 1998) compares students who had to repeat a school level with those who did not. The results suggested no differences in their self-esteem, but there were differences in the academic and behavioural dimensions in favour of the students who had not retaken a year and differences in the athletic and physical appearance dimensions in favour of those who had done so. An analysis of the importance that they awarded to the different dimensions of self-concept showed that the students who had not retaken a year attached greater importance to academic competence, whereas those with a history of academic failure valued athletic competence more; there were no differences between them in relation to the other dimensions. These results reveal a reorganisation of self-concept that involves a devaluation of the academic dimension and an investment in others (in this case, athletic competence), as suggested by Harter (1993, 1999), but this reorganisation coexists with a perception of a smaller adjustment in the behavioural dimension, in accordance with Robinson and colleagues (Robinson and Breslav 1996; Robinson and Tayler 1986, 1991; Robinson et al. 1990). However, an analysis that took into consideration the repetition of a year and self-esteem as independent variables (self-esteem operationalised upwards or downwards for the upper and lower quartiles of the distribution) showed that as far as the behavioural dimension was concerned, the differences were between the group that had achieved academic success and possessed high self-esteem on the one hand and the two groups with low self-esteem on the other, whilst there were no significant differences between the former and the group that had retaken a year and had high self-esteem. These results allow us to question some of the assumptions behind the model proposed by Robinson and colleagues, particularly with regard to the adoption of deviant behaviours as a manifestation of the inversion of values in order to protect self-esteem.

Another study (Alves Martins and Peixoto 2000) with 139 ninth-grade students also revealed the absence of differences between the self-esteem of students with records of academic success or failure. An analysis of the different dimensions of self-concept made it possible to see that successful students displayed higher levels of self-perception in the field of academic competence, whilst the students who had experienced academic failure revealed higher perceptions of competence in relation to romantic appeal. At the same time, the latter students devalued academic competence and behavioural dimensions.

Finally, another study involving 838 students from the seventh to the ninth grades (Alves Martins et al. 2002) also found that there were no differences between the self-esteem of the academically successful and unsuccessful eighth and ninth grade students. However, the seventh-grade students who had experienced academic failure presented lower levels of self-esteem than their successful counterparts. An analysis of the different dimensions of selfconcept, the importance attached to them and attitude towards school showed that the eighthand ninth-grade students appeared to use various mechanisms to protect their self-esteem: devaluing school-related areas, increasingly adopting disruptive behaviours and investing in 
the field of interpersonal relations with members of the opposite sex. However, these mechanisms seem not to have been enough for the seventh-grade students to maintain their self-esteem at acceptable levels - something that may have been due to their attaching greater value to school.

\section{Aims and hypotheses}

Our first aim was to analyse differences in self-esteem according to academic achievement. This statement of intent is necessary as the search for strategies of self-esteem protection in a school context only makes sense if achievers (those who have never retaken a year) and underachievers (those who have retaken at least 1 year in their school history) do not differentiate in terms of self-esteem.

According to the literature reviewed, academic failure does not always necessarily lead to a reduction in self-esteem. The studies we have mentioned show the lack of differences between the self-esteem-related values of students whose academic history did or did not include retaking years. Thus, there are no differences between the self-esteem experienced by achievers and by underachievers (hypothesis 1 ).

The absence of differences in the self-esteem of students with different degrees of academic success may be explained by self-esteem protection mechanisms. These mechanisms are activated when a person's self-esteem is threatened. It is thought that these strategies entail a decreased investment in school and that they can be accompanied by the appearance of disruptive behaviours (Kaplan et al. 1994; Robinson and Tayler 1986; Senos 1997). On the other hand, other studies reveal that the protection of self-esteem can be achieved by reorganising self-concept in a process in which there is a decreased investment in the threatening area (in this case the academic one) and an investment in other, potentially more gratifying areas (Peixoto 1998). Thus, some results move in the direction of social identity theory, particularly as regards the adoption of more negative attitudes towards school (Alves Martins et al., 2002; Robinson and Tayler 1986; Senos 1997), whilst others indicate that selfesteem is protected by reorganising self-concept (Alves Martins and Peixoto 2000; Peixoto 1998). Accordingly, our second aim was to determine what strategies were undertaken to protect self-esteem when facing academic failure. Our hypothesis was that for some students, the protection of self-esteem can be achieved through a reorganisation of self-concept and/or the adoption of more negative attitudes towards school (hypothesis 2). To examine this second hypothesis, we sought to analyse the profiles associated with different levels of selfesteem by trying to determine whether high levels in the case of students who have experienced academic failure in the past are preferentially associated with more negative attitudes towards school, or with a difference in the way in which self-concept is organised, or if both strategies are pursued alongside one another.

Finally, we also wanted to analyse if grade - the school year-introduces differences in the strategies of self-esteem protection used by students. Here, we have not stated any hypothesis due to the absence of research that addresses this issue.

\section{Method}

\section{Participants}

The participants were 953 adolescents in the 7th, 9th and 11th grades from four public schools in Lisbon, with 456 male and 497 female. Ages varied from 12 to 20, with an 
average of 14 years and 10 months. Their parents' academic qualifications (taken as the average of the mother and father) were as follows: 270 students had parents with less than the sixth grade of schooling; 330 students' parents had completed between the 6th and the 12th grades; and 274 students came from families where the parents had at least attended university ( 79 students did not provide information in this respect). Of the 953 student respondents, 601 had never retaken a school year, whilst 352 said that their academic past included at least one such occurrence. From those who had retaken, 51.7\% had retaken once, $30.1 \%$ twice and $18.2 \%$ at least three times.

Measurement

Two instruments have been used: a self-concept and self-esteem scale (Peixoto and Almeida 1999) and a scale for attitudes towards school (Alves Martins and Peixoto 2000; Peixoto et al. 2001).

Self-concept and self-esteem scale The self-concept and self-esteem scale has been constructed from the set of items used in the Portuguese adaptation (Peixoto et al. 1997) of Harter's Self-Perception Profile for Adolescents (Harter 1988). In addition to the existing subscales (Scholastic Competence-e. g. "Some young people understand everything that teachers teach in classes"; Social Acceptance-e. g. "Some young people are really well accepted by their colleagues"; Athletic Competence-e. g. "Some young people are very good at playing any kind of sport"; Physical Appearance-e.g. "Some young people don't feel very satisfied with their appearance"; Romantic Appeal-e.g. "Some young people easily manage to date the people they fall in love with"; Behaviour-e.g. "Some young people easily get into trouble with the things they do"; Close Relationships-e.g. "Some young people have a special friend they can share their secrets with"; and Self-Esteeme.g. "Some young people like the kind of person they are"), we added two new dimensions: Competence in Language (e.g. "Some young people manage to express themselves very well") and Competence in Mathematics (e.g. "Some young people manage to solve maths problems very quickly"). We have included these two subscales because the research was carried out in a scholastic context - a situation in which it is advisable to assess academic self-concept in relation to specific facets of school life and not just the overall picture (Marsh et al. 1988). We have also changed the format of the scale so that it only presents one statement instead of the two on Harter's (1988) original scale. However, we retained the use of the third person of the plural. We chose this format essentially for two reasons: on the one hand, this version is quite long and so we wanted a faster way of applying the scale, and on the other, in a study on the format of the scale, Wichstrøm (1995) obtained better results in terms of reliability, convergent validity and factorial validity with a format that only uses one statement per item than with the original format.

The scale originally consisted of 70 items, but successive analyses reduced it to 51 (five for each specific dimension of self-concept and six for the self-esteem assessment subscale). When we formulated the items, we made sure there was a balance between those that reflect positive self-perceptions and those that reveal negative ones. Like Harter's Self-Perception Profile for Adolescents (Harter 1988), we chose to include an importance scale. This was originally composed of 27 items, but the final version contained 18 - two for each specific dimension of self-concept. The items are identical to those of the self-concept dimensions but rephrased in terms of importance (e.g. "Some young people think that it is important to be a good student at school" for Importance given to School Competence; "Some young people think that it is important to be acknowledged by their colleagues" for importance 
given to Social Acceptance; "Some young people think that is important to be a good student in Portuguese subjects" for Importance given to Portuguese Language Competence; "Some young people don't think it is important to achieve good grades at Mathematics" for Importance given to Competence in Mathematics. As with the self-concept and self-esteem scale, around half the items on the importance scale were formulated positively and half negatively.

In this study, we used as measures academic self-concept (an aggregated measurement comprising school competence, Portuguese language competence and competence in mathematics), social self-concept (composed of social acceptance and close relationships), presentation self-concept (formed by physical appearance, athletic competence and romantic appeal), the importance given to academic self-concept (one which comprises the same dimensions as for the scale of self-concept) and self-esteem (obtained averaging the scores of the items in the self-esteem subscale. The reliability was 0.81 for academic and social self-concept, 0.85 for presentation self-concept, 0.77 for the importance placed on academic self-concept and 0.76 for the self-esteem measure.

Attitudes towards School Scale The attitudes towards school scale had already been used in earlier studies (Alves Martins and Peixoto 2000; Peixoto et al. 2001) and is divided into two factors: one groups together items concerning rules of conduct in the classroom; the other is composed of items that look at attitudes towards work in the classroom (Peixoto et al. 2001; Peixoto 2003). The two factors that had been identified in the previous studies can be defined as follows: Attitude towards schoolwork - this dimension encompasses items that seek to assess whether a student displays a committed attitude towards school tasks. For example: "Some students are interested in work at school", or "Some students get their homework done early" (Cronbach's alpha, 0.82); Attitude towards rules of conduct at school - this dimension groups together the items which concern behaviours that are displayed at school, which may or may not comply with the established rules. For example: "Some students eat in classes", "Some students copy in tests", or "Some students drink alcohol at school" (Cronbach's alpha, 0.81 ). The total internal consistency for the scale was 0.87 .

\section{Procedure}

The instruments have been applied in class during course times. Students were informed about the study objectives and its confidentiality. The instructions were presented collectively. Data analysis was done with SPSS (version 16 for windows). In data analysis, we carried out separate analysis for students that had never retaken and for those that had retaken at least once. Here, we did not consider the number of times the student has repeated because previous investigation showed that in relation to self-concept, retention is what differentiates students and not the number of retentions (Peixoto 2003; Veiga 1996).

\section{Results}

School achievement and self-esteem

In order to answer our first aim, we began by analysing the differences in self-esteem in accordance with the students' status at school. To this end, we carried out a covariance analysis in which we controlled the effects of the parents' academic qualifications and used 
Table 1 Means and standard deviation for self-esteem in function of school achievement

\begin{tabular}{|c|c|c|c|c|}
\hline & \multicolumn{2}{|c|}{ Achievers } & \multicolumn{2}{|c|}{ Underachievers } \\
\hline & M & SD & M & SD \\
\hline Total & 3.01 & .519 & 2.98 & 0.520 \\
\hline 7th Grade & 3.01 & .531 & 2.88 & 0.510 \\
\hline 9th Grade & 3.02 & .538 & 2.96 & 0.539 \\
\hline 11th Grade & 3.01 & .487 & 2.93 & 0.495 \\
\hline
\end{tabular}

academic achievement (students who had or had not retaken a year), gender and grade as independent variables. ${ }^{1}$ The results showed that there were no significant differences as a result of academic achievement $(F(1,859)=2.42, p=0.120)$. We also found that there were no interaction effects between academic achievement and the other two independent variables. If we look at Table 1, we can see that the average values for the two groups are close to one another, with the students whose school career included having retaken years displaying slightly lower average self-esteem values.

Analysis of the strategies of self-esteem protection

As we said earlier, in this study, we sought to determine whether the protection of selfesteem is due to an investment in other dimensions of self-concept, a devaluation of academic competences or the development of negative attitudes towards school, and also whether these processes occur on their own or together. In order to try to answer these questions, we performed a cluster analysis solely for the students who had retaken a year at some point in their school career. To perform this analysis, we used the following variables: self-esteem, attitude towards school, importance attached to academic self-concept and the self-concept values for the higher dimensions of selfconcept (academic self-concept, social self-concept and presentation self-concept). We chose these variables because the literature indicated that the possible self-esteem protection strategies included: decreased investment in the areas of self-concept that are potentially threatening to self-esteem (in the case of students who are experiencing academic failure, the academic area); investment in potentially more gratifying areas; and the development of negative attitudes towards school (Harter 1993, 1998, 1999; Kaplan et al. 1994; Peixoto 1998; Robinson and Tayler 1986; Senos 1997).

In the cluster analysis, we followed the methodology proposed by Hair et al. (1995) and used a hierarchical classification method, followed by a non-hierarchical one. We thus began with an analysis using the Ward method and the squared Euclidian distance as proximity measure, followed by another analysis using the K-means method. In all the analyses, we consistently used the standardised values for the selected measurements. In order to decide the number of clusters, we analysed the dendrogram from the Ward method which showed that it would be possible to divide the sample of students who had retaken a year into two, three, five or six groups. By analysing the profiles for each group separation hypothesis, we found that two or three clusters would be poor solutions which would differ

\footnotetext{
${ }^{1}$ Here, we used gender and grade as independent variables in order to look for possible interaction effects with academic success. We are not concerned with the main effects of these variables and we will not report them.
} 
from one another in terms of the average values that each group presented for the different variables, but would possess similar profiles. The six-cluster solution was also discarded because the sixth cluster was composed of too few subjects (11). We therefore opted for a five-cluster solution and performed a K-means analysis. In order to validate the cluster solution, the underachievers group was randomly split into two and separate analyses were carried out in each (Aldenderfer and Blashfield 1984; Hair et al. 1995). The subsequent comparison, using analyses of variance, showed that there were no significant differences between the profiles obtained.

Despite the fact that cluster analysis is normally used to create typologies, this was not the purpose in the present study. Here, it was used as a technique for trying to uncover any differences in the profiles of the students in different situations in terms of their attitudes towards school, self-concept and the value they attached to the academic dimension of selfconcept. We therefore decided not to denominate the different groups we found-the procedure that would usually be adopted in a cluster analysis - but rather just to describe them. Figure 1 gives the profiles we obtained for each of the clusters we found in the total sample of students who had retaken a year.

The first cluster (R1), which was composed of 66 students, is characterised by a slightly below-average self-esteem, very positive attitudes towards school, a devaluation of academic self-concept, low academic self-concept and social and presentation selfconcepts that were also slightly below average. The students who were grouped in the second cluster (R2, 77 students) were characterised by low self-esteem, clearly negative attitudes towards school, a devaluation of academic competences, about average academic and presentation self-concepts and quite a low social self-concept. The third group (R3) was made up of 53 students who presented the lowest levels of self-esteem and a negative attitude towards school, attached a high degree of value to academic self-concept and had low self-concepts in every dimension of the higher orders of self-concept. The fourth cluster (R4) grouped together 97 adolescents who displayed the highest levels of selfesteem and the most positive attitudes towards school, awarded substantial value to academic self-concept and also possessed high self-concepts. Lastly, the fifth cluster (R5) included 59 students characterised by a display of positive self-esteem, a negative attitude towards school, a devaluation of academic self-concept, low academic self-concept and high social and presentation self-concepts.

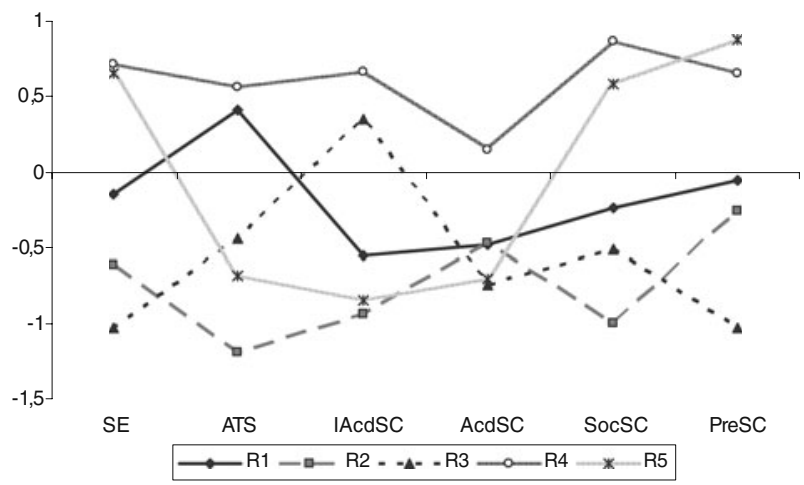

Fig. 1 Profiles from cluster analysis to underachievers. $S E$ self-esteem, ATS attitude towards school, IAcdSC importance given to academic self-concept, $A c d S C$ academic self-concept, SocSC social self-concept, PreSC presentation self-concept 
A comparative analysis of the different profiles shows that among students who had retaken a year, positive self-esteem was associated with the existence of high levels of selfconcept - particularly the non-academic dimensions of self-concept - as we can see from the profiles of groups R4 and R5. The students who were grouped together in cluster 4 (R4) displayed the highest levels of academic self-concept in which they differed significantly from their colleagues (Tukey, $p \leq .003$ for all the comparisons) despite the fact that the analysis of academic achievement reveals the absence of significant differences between the various groups. For the students in the fifth cluster (R5), in addition to the positive selfconcepts in the non-academic dimensions of self-concept, maintaining positive levels of self-esteem seems to be associated with a devaluation of academic competences and negative attitudes towards school. However, the relationship between attitude towards school and self-esteem is not very clear inasmuch as we find positive attitudes associated with low levels of self-esteem (R1), high self-esteem (R4) and negative attitudes associated with low self-esteem (R2 and R3). It would therefore seem that adopting negative attitudes towards school is not enough in its own right to maintain positive self-esteem in students with a history of academic failure.

Comparison of profiles in function of school achievement Following the process of validating the five-cluster solution for underachievers, a similar analysis was performed on the remaining students, that is, on those who had never retaken a year. The analysis was carried out because we wanted to ascertain whether there was any specific profile for students who had repeated a grade. In this analysis, the standardised values for the variables that were included in the process of analysis were used again, utilising the centroids that had been obtained in the first analysis using the K-means method, as the initial values. Figure 2 shows the comparison between the profiles obtained in the cluster analysis for both groups (achievers and underachievers). Looking at the profiles displayed in Fig. 2, we can see that for the first four comparisons, they are quite similar, with students that had never retaken a year following the same pattern of results of those who had experienced failure in their school careers. The profiles in the fifth comparison (R5 and NR5) are the only ones where achievers seem differentiated from underachievers.

In order to analyse differences in the profiles of the students with contrasting academic statuses, we performed multivariate analyses of variance for each pair of clusters (the cluster from underachievers and the corresponding cluster in the achieving group) using Bonferroni correction. The results of this analysis showed that despite the similitude in the patterns displayed, they differ in the values presented in several variables. The sole exception is cluster 2 (R2 and NR2) (Pillai's trace $=0.041, F(6,183)=1.3, p=0.259$ ). For the remaining pairs, multivariate analyses of variance show significant differences (Pillai's trace $=0.295, F(6,209)=$ 14.56, $p<0.001$ for cluster 1; Pillai's trace $=0.173, F(6,161)=5.6, p<0.001$ for cluster 3; Pillai's trace $=0.998, F(6,226)=9.63, p<0.001$ for cluster 4; Pillai's trace $=0.403, F(6,141)=15.88, p<$ 0.001 for cluster 5). In the first pair of clusters (R1 vs. NR1), achievers differentiate from underachievers in the values presented for self-esteem $(F(1,214)=14.03, p<.001)$, attitude towards school $(F(1,214)=12.12, p<0.001)$, importance attached to academic self-concept $(F$ $(1,214)=29.47, p<0.001)$ and academic self-concept $(F(1,214)=42.68, p<0.001)$. In cluster 3 (R3 vs. NR3), differences arise concerning attitudes towards school $(F(1,166)=14.46, p<$ $0.001)$ and academic self-concept $(F(1,166)=10.06, p=0.002)$. In the fourth cluster (R4 vs. NR4), achievers differentiated from underachievers in self-esteem $(F(1,231)=8.02, p=0.005)$, importance attached to academic self-concept $(F(1,231)=16.82, p<0.001)$ and academic selfconcept $(F(1,231)=36.45, p<0.001)$. In the last pair of comparisons (R5 vs. NR5), differences occur in the importance attached to academic self-concept $(F(1,146)=16.03, p<0.001)$, 

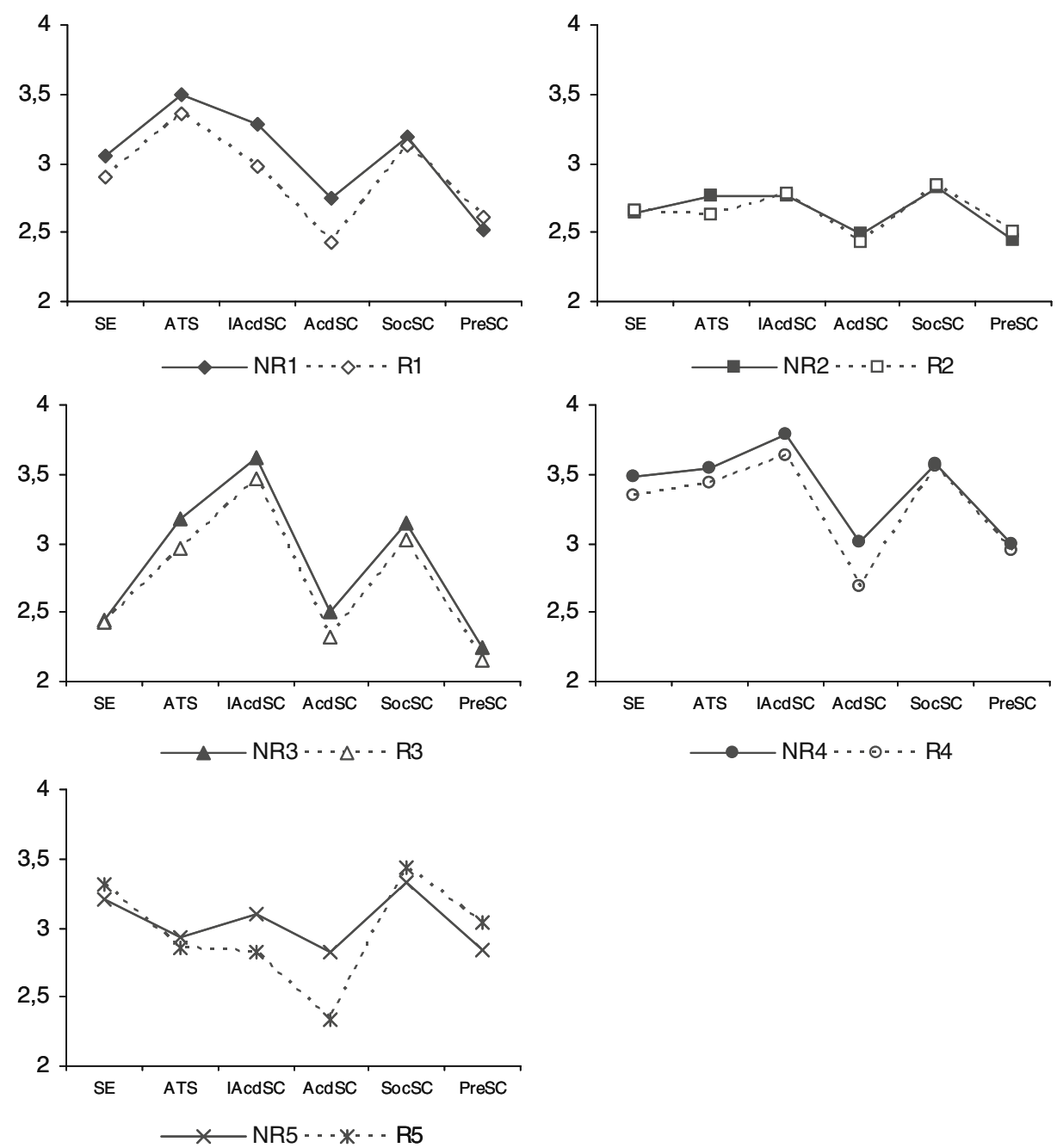

Fig. 2 Comparison of profiles of underachievers $(R)$ and achievers $(N R)$. SE self-esteem, ATS attitude towards school, IAcdSC importance given to academic self-concept, AcdSC academic self-concept, SocSC social self-concept, PreSC presentation self-concept

academic self-concept $(F(1,146)=58.3, p<0.001)$ and in presentation self-concept $(F(1,146)=$ $11.7, p=0.001)$. With the exception of presentation self-concept for cluster 5 , in all variables, achievers show higher values than underachievers. In cluster 5, those students who had retaken a year present higher presentation self-concept than their colleagues with better school achievement.

Contributions from self-representations and attitudes towards school to self-esteem Besides the comparative analyses of the groups of students who had and had not retaken a year, we also performed multiple linear regression analyses for each cluster. This analysis was performed in order to discern which variables presented stronger relationships to selfesteem, namely to see if positive self-esteem is associated with the devaluation of academic 
self-concept and/or negative attitudes towards school. Here, we used attitude towards school, the importance attached to academic self-concept and the self-concept values for the higher dimensions of self-concept as predictor variables and self-esteem as the criterion variable. We used the stepwise method for this analysis because what we wanted to do was to analyse which variables were significantly associated with self-esteem in each group.

Table 2 shows that presentation self-concept is positively associated with self-esteem in most of the groups. This is understandable, bearing in mind that it includes the physical appearance dimension, which is normally one of the dimensions that are most closely correlated with self-esteem (Harter 1993, 1999; Peixoto and Mata 1993). Secondly, in the case of the students who had retaken a year, academic self-concept is only associated with self-esteem in one of the groups (R2 - one of those with low self-esteem), whereas this association is significant for all three groups of students who had never retaken a year, two of which displayed positive levels of self-esteem (NR4 and NR1). These results allow us to see that there was a stronger association between self-esteem and academic self-concept among students who had not retaken a year. This is corroborated by the stronger correlation between these two variables which these students displayed compared to their colleagues who had retaken a year $(r=0.40, p<0.01$ vs. $r=0.30, p<0.01$; the difference in the magnitude of the correlations is significant for $p=0.045$ ). Probably the most interesting

Table 2 Results of the multiple regression analyses of the variables used to classify students in terms of selfesteem for the different clusters

\begin{tabular}{|c|c|c|c|c|c|c|}
\hline & & Variable & $B$ & SE $B$ & $\beta$ & $R^{2}$ \\
\hline \multirow[t]{9}{*}{ Underachievers } & $\mathrm{R} 1$ & AUTOAPRE & 0.30 & 0.14 & 0.26 & 0.07 \\
\hline & \multirow[t]{3}{*}{$\mathrm{R} 2$} & AUTOACA & 0.47 & 0.12 & 0.41 & \\
\hline & & IAUTSOC & -0.36 & 0.12 & -0.32 & \\
\hline & & AUTOSOC & 0.34 & 0.12 & 0.28 & 0.22 \\
\hline & R3 & AUTOAPRE & 0.51 & 0.15 & 0.43 & 0.18 \\
\hline & \multirow[t]{2}{*}{$\mathrm{R} 4$} & AUTOSOC & 0.45 & 0.17 & 0.26 & \\
\hline & & AUTOAPRE & 0.23 & 0.09 & 0.24 & 0.13 \\
\hline & \multirow[t]{2}{*}{ R5 } & IAUTACA & -0.26 & 0.09 & -0.35 & \\
\hline & & AUTOAPRE & 0.23 & 0.10 & 0.26 & 0.20 \\
\hline \multirow[t]{11}{*}{ Achievers } & \multirow[t]{2}{*}{ NR1 } & AUTOACA & 0.24 & 0.06 & 0.30 & \\
\hline & & IAUTAPRE & -0.17 & 0.07 & -0.19 & 0.12 \\
\hline & \multirow[t]{3}{*}{ NR2 } & AUTOAPRE & 0.39 & 0.08 & 0.38 & \\
\hline & & AUTOSOC & 0.44 & 0.09 & 0.39 & \\
\hline & & AUTOACA & 0.18 & 0.09 & 0.16 & 0.29 \\
\hline & \multirow[t]{2}{*}{ NR3 } & AUTOAPRE & 0.31 & 0.10 & 0.29 & \\
\hline & & AUTOSOC & 0.30 & 0.13 & 0.21 & 0.14 \\
\hline & \multirow[t]{3}{*}{ NR4 } & AUTOAPRE & 0.28 & 0.07 & 0.32 & \\
\hline & & AUTOSOC & 0.38 & 0.12 & 0.2 & \\
\hline & & AUTOACA & 0.14 & 0.07 & 0.16 & 0.22 \\
\hline & NR5 & AUTOSOC & 0.29 & 0.12 & 0.23 & 0.05 \\
\hline
\end{tabular}

IAUTACA importance attached to academic self-concept, IAUTSOC importance attached to social selfconcept, IAUTAPRE importance attached to presentation self-concept, AUTOACA academic self-concept, $A U T O S O C$ social self-concept, AUTOAPRE presentation self-concept 
result of this analysis is the association between the importance attached to academic competences and self-esteem, which we found in the case of the students in the fifth cluster that had retaken a year. It confirms the intuitive conclusion suggested by the analysis of this group's profile - for these students, maintaining self-esteem appears to be associated with a devaluation of the academic dimensions of self-concept. What is more is that the existence of positive self-perceptions in one of the non-academic dimensions of self-conceptpresentation self-concept-also makes a significant contribution to this conclusion. At the same time, the profile analysis is also confirmed in the other group of students who had retaken a year and whose self-esteem was clearly positive due to the fact that the latter was dependent above all on some of the non-academic dimensions of self-concept being positive.

Effects of grade on self-esteem protection In order to analyse possible effects of the grade on the use of strategies of self-esteem protection, we compared the composition of clusters in terms of grade both for students that had retaken and for those who had not (Tables 3 and 4). An analysis of the composition of the groups, for students that had not retaken a year, showed that there were significant differences in terms of grade year $\left(\chi^{2}(8)=23.71, p=0.02\right)$. This effect was predominantly due to the fact that the seventh-grade students were more asymmetrically distributed between the clusters than their 9th and 11th grade counterparts. There were more of them in the first and fourth groups (NR1 and NR4), which were characterised by the display of positive attitudes towards school. We can also see that there were fewer seventh-grade students in the fifth cluster compared to their 9th and 11th grade colleagues.

For the students whose school career includes at least one repeated year (Table 4), we also found an effect of grade $\left(\chi^{2}(8)=13.8, p=0.043\right.$; one-tail hypothesis). This effect was above all due to the smaller number of seventh-grade pupils in the fifth cluster.

Table 3 Number and percentage of achievers in each cluster by grade

\begin{tabular}{|c|c|c|c|}
\hline & \multicolumn{3}{|l|}{ Grade } \\
\hline & 7 th & 9 th & 11th \\
\hline \multirow[t]{2}{*}{ NR 1} & 59 & 41 & 36 \\
\hline & $29.6 \%$ & $18.6 \%$ & $19.6 \%$ \\
\hline \multirow[t]{2}{*}{ NR 2} & 31 & 47 & 39 \\
\hline & $15.6 \%$ & $21.4 \%$ & $21.2 \%$ \\
\hline \multirow[t]{2}{*}{ NR 3} & 35 & 39 & 33 \\
\hline & $17.6 \%$ & $17.7 \%$ & $17.9 \%$ \\
\hline \multirow[t]{2}{*}{ NR 4} & 55 & 46 & 35 \\
\hline & $27.6 \%$ & $20.9 \%$ & $19.0 \%$ \\
\hline \multirow[t]{2}{*}{ NR 5} & 19 & 47 & 41 \\
\hline & $9.5 \%$ & $21.4 \%$ & $22.3 \%$ \\
\hline \multirow[t]{2}{*}{ Total } & 199 & 220 & 184 \\
\hline & $100 \%$ & $100 \%$ & $100 \%$ \\
\hline
\end{tabular}


Table 4 Number and percentage of underachievers in each cluster by grade

\begin{tabular}{|c|c|c|c|}
\hline & \multicolumn{3}{|l|}{ Grade } \\
\hline & 7 th & 9 th & 11 th \\
\hline \multirow[t]{2}{*}{$\mathrm{R} 1$} & 21 & 26 & 19 \\
\hline & $22.1 \%$ & $17.3 \%$ & $17.8 \%$ \\
\hline \multirow[t]{2}{*}{$\mathrm{R} 2$} & 24 & 37 & 16 \\
\hline & $25.3 \%$ & $24.7 \%$ & $15 \%$ \\
\hline \multirow[t]{2}{*}{$\mathrm{R} 3$} & 12 & 22 & 19 \\
\hline & $12.6 \%$ & $14.7 \%$ & $17.8 \%$ \\
\hline \multirow[t]{2}{*}{$\mathrm{R} 4$} & 31 & 37 & 29 \\
\hline & $32.6 \%$ & $24.7 \%$ & $27.1 \%$ \\
\hline \multirow[t]{2}{*}{ R5 } & 7 & 28 & 24 \\
\hline & $7.4 \%$ & $18.7 \%$ & $22.4 \%$ \\
\hline \multirow[t]{2}{*}{ Total } & 95 & 150 & 107 \\
\hline & $100 \%$ & $100 \%$ & $100 \%$ \\
\hline
\end{tabular}

\section{Discussion}

In this study, we intended to analyse the relationship between self-representations and school achievement, namely the impact of grade retention on self-esteem and on the strategies of self-esteem protection used by underachievers. Our first hypothesis stated that students who had retaken a year would present identical levels of self-esteem to those of the students who had never retaken. The results presented show that there are no significant differences in the levels of self-esteem displayed by students who have and have not retaken at least one grade in their school careers. This corroborates the results of other research which have shown that students with different academic statuses present similar values for self-esteem (Alves Martins and Peixoto 2000; Alves Martins et al. 2002; Peixoto 1998; Robinson et al. 1990; Senos 1997; Senos and Diniz 1998). Despite the lower sense of academic competence (Alves Martins and Peixoto 2000; Alves Martins et al. 2002; Peixoto 1998, 2003), students that had retaken do not lose their sense of worth. Taking the absence of differences in self-esteem as our starting point, we can advance the hypothesis that students who have retaken a year may employ strategies to protect their self-esteem against the threat posed by low academic achievement.

Our second hypothesis sought to point out the strategies of self-esteem protection mobilised by students with lower academic status. Based on previous research, we stated that self-esteem protection will be achieved by a reorganisation of self-concept and/or the adoption of more negative attitudes towards school. In fact, previous research was not perfectly clear about this subject, with results pointing to self-concept reorganisation and equally to the adoption of more negative attitudes towards school (Alves Martins and Peixoto 2000; Alves Martins et al. 2002; Peixoto 2003). The results of the present research enable us to clarify this issue a little further. We can see that for some students with a history of repeating years, maintaining self-esteem at acceptable levels is linked to the devaluation of academic competences and to less positive attitudes towards school. However, the devaluation of academic competences makes a more significant contribution to the self-esteem values displayed by students than does the adoption of negative attitudes towards school. Negative attitudes towards school seem to be associated more with low self-esteem. Only in the fifth cluster, less positive attitudes towards school are linked to 
positive self-esteem. However, when we look at the results of regression analysis, we can see that for students in this particular cluster, it is the devaluation of academic competences that contributes to self-esteem and not the adoption of negative attitudes towards school. Our results thus appear to be closer to the theses put forward by Harter $(1993 ; 1999)$ than to those presented by Robinson (Robinson and Tayler 1986, 1991; Robinson et al. 1990; Robinson and Breslav 1996). This does not mean, however, that under certain conditions, the protection of self-esteem was not carried out throughout the construction of subcultures where the leitmotiv is precisely "to be bad at school". As Robinson and Breslav (1996) have stated, this could happen when concomitant with the category of "bad student", there occurs a feeling of belonging to clearly identified social groups.

The results presented here also suggest that devaluing academic competences is not enough to maintain self-esteem. For example, the subjects in cluster 2 are those who attribute lesser importance to academic self-concept and also who present less positive attitudes towards school, nevertheless exhibit low self-esteem. Therefore, these results suggest that it is not enough to devalue academic self-concept in order to maintain a positive sense of worth. It also seems that this requires positive self-perceptions in nonacademic dimensions of self-concept. Presentation self-concept seems to be particularly important in this respect. This result is not surprising if we bear in mind that presentation self-concept is constituted by the physical appearance, romantic appeal and athletic competence dimensions. As a number of different studies (Harter 1993, 1999; Peixoto and Mata 1993; Williams and Currie 2000) show, physical appearance is an especially important dimension when it comes to defining self-esteem. In other words, the fact that a person feels comfortable with his/her body makes a positive contribution to his/her feeling of global self-worth. On the other hand, the romantic appeal dimension has appeared to be one in which students with a history of academic failure see themselves more favourably than their successful colleagues - particularly in the case of the ninth grade (Alves Martins and Peixoto 2000; Alves Martins et al. 2002; Peixoto 2003). So for these students, investing in interpersonal relationships with counterparts of the opposite sex may make a positive contribution to maintaining self-esteem at acceptable levels.

Our last goal was to analyse whether grade introduces differences in the strategies of self-esteem protection mobilised by students. The results presented suggest the existence of grade-related effects which condition the strategies that students adopt in order to maintain self-esteem. It seems that it was more difficult for the younger students to maintain selfesteem by adopting strategies that imply devaluing academic competences and opposing the values and rules which are conveyed in school. As we have seen, the youngest students are clearly in the minority in the group in which positive self-esteem is associated with the importance attached to the academic dimension of self-concept and the adoption of less positive attitudes towards school. This result suggests that adults' (school/family) rules and values have a greater influence on younger students and that this prevents them from adopting school devaluation strategies (Peixoto 2003).

\section{Limitations and Implications}

According to the results of the present research, maintaining positive levels of self-esteem in the face of situations involving academic failure seems to be associated with the existence of positive self-perceptions in non-academic dimensions of self-concept and in some cases with the devaluation of school-related competences. However, the methodology employed does not enable us to determine whether the existence of positive self-concepts in non-academic dimensions predates the academic failure and thus makes it easier to maintain 
positive self-esteem or whether they arise following a greater investment in these areas as a reaction to a threatened self-esteem. Similarly, we can ask identical questions in relation to the devaluation of school-related competences, given that although this appears to be a plausible means for subjects to protect their self-esteem (Harter 1993, 1999), our research was designed in a way that does not make it possible to analyse the process which led students to devalue school. Despite these limitations, the present study has enabled us to note the existence of developmental factors that appear to affect the strategies used to protect self-esteem. It is less likely that younger students will protect their selfesteem by devaluing school-related competences and even less probable that they will do so by constructing anti-school cultures.

In addition to the above conclusions, it seems to us that it is also possible to draw implications of a conceptual and methodological nature from the results of the present research work. From the methodological point of view, we feel that the decision to look for individual patterns on the basis of psychological variables, rather than taking the results of a global sample or dividing it based on demographic variables, was a valid one. The differential analyses based on academic success could lead one to confuse the roles of attitudes towards school and the devaluing of academic self-concept in the preservation of sense of worth and to accept the hypothesis that both lead to positive self-esteem (cf. Peixoto 2003). The use of cluster analyses gave a substantially clearer picture of the situations in which students exhibited positive levels of self-esteem and thus enabled us to conclude that it was the devaluation of the academic facet of self-concept associated with positive non-academic self-concepts that contributed to the maintenance of a positive sense of worth.

Although our results shed a little more light on the issue of the association between nonacademic self-concept and positive self-esteem in students with a history of academic failure, they do not clarify the nature of the processes which underlie this association. It would only be possible to analyse this question by conducting longitudinal studies that permit the establishment of temporal nexuses and thus show whether the existence of positive self-representations in non-academic dimensions of self-concept arise as a consequence of a greater investment in these areas in order to deal with a threat to selfesteem or whether those self-representations predate academic failure.

Acknowledgments This research was supported by grants from the Science and Technology Foundation (POCI 2010).

\section{References}

Aldenderfer, M. S., \& Blashfield, R. K. (1984). Cluster analysis. Beverly Hills: Sage.

Alves Martins, M., \& Peixoto, F. (2000). Self-esteem, social identity and school achievement in adolescence. Psychology: The Journal of the Hellenic Psychological Society, 7, 278-289.

Alves Martins, M., Peixoto, F., Gouveia Pereira, M., Amaral, V., \& Pedro, I. (2002). Self-esteem and academic achievement among adolescents. Educational Psychology, 22, 51-62.

Branscombe, N. R., \& Wann, D. L. (1994). Collective self-esteem consequences of out-group derogation when a valued social identity is on trial. European Journal of Social Psychology, 24, $641-657$.

Choi, N. (2005). Self-efficacy and self-concept as predictors of college students' academic performance. Psychology in the Schools, 42, 197-205.

Covington, M. V. (1984). The motive for self-worth. In R. E. Ames \& C. Ames (Eds.), Research on motivation in education: Student motivations (Vol. 1, pp. 77-113). San Diego: Academic. 
Hair, J. F., Jr., Anderson, R. E., Tatham, R. L., \& Black, W. C. (1995). Multivariate data analysis with readings, 4th ed.. New Jersey: Prentice-Hall International.

Harter, S. (1988). Manual for the self-perception profile for adolescents. Denver: University of Denver.

Harter, S. (1993). Causes and consequences of low self-esteem in children and adolescents. In R. F. Baumeister (Ed.), Self-esteem: The puzzle of low self-regard (pp. 87-116). New York: Plenum.

Harter, S. (1998). The development of self-representations. In W. Damon (Series Ed.) \& N. Eisenberg (Vol. Ed.), Handbook of child psychology: vol. 3. Social, emotional and personality development ( $5^{\mathrm{a}}$ ed., pp. 553617). New York: Wiley.

Harter, S. (1999). The construction of the self: A developmental perspective. New York: Guilford.

Hoge, D. R., Smit, E. K., \& Crist, J. T. (1995). Reciprocal effects of self-concept and academic achievement in sixth and seventh grade. Journal of Youth and Adolescence, 24, 295-314.

Jackson, S. A., Thomas, P. R., \& Marsh, H. W. (2001). Relationships between flow, self-concept, psychological skills, and performance. Journal of Applied Sport Psychology, 13, 129-153.

Judge, T. A., Erez, A., \& Bono, J. E. (1998). The power of being positive: The relation between positive selfconcept and job performance. Human Performance, 11, 167-187.

Kaplan, H. B. (1982). Self-attitudes and deviant behavior: New directions for theory and research. Youth and Society, 14, 185-211.

Kaplan, H. B., \& Lin, C. (2000). Deviant identity as a moderator of the relation between negative selffeelings and deviant behavior. Journal of Early Adolescence, 20, 150-177.

Kaplan, D. S., Peck, B. M., \& Kaplan, H. B. (1994). Structural relations model of self-rejection, disposition to deviance, and academic failure. Journal of Educational Research, 87, 166-173.

Leary, M. R., Tambor, E. S., Terdal, S. K., \& Downs, D. L. (1995). Self-esteem as an interpersonal monitor: The sociometer hypothesis. Journal of Personality and Social Psychology, 68, 518-130.

Liu, X., Kaplan, H. B., \& Risser, W. (1992). Decomposing the reciprocal relationship between academic achievement and general self-esteem. Youth and Society, 24, 123-148.

Lyon, M. A. (1993). Academic self-concept and its relationship to achievement in a sample of junior high school students. Educational and Psychological Measurement, 53, 201-210.

Marsh, H. W. (1987). The big-fish-little-pond effect on academic self-concept. Journal of Educational Psychology, 79, 280-295.

Marsh, H., Byrne, B. M., \& Shavelson, R. J. (1988). A multifaceted academic self-concept: Its hierarchical structure and its relation to academic achievement. Journal of Educational Psychology, $80,366-380$.

Marsh, H. W., \& Craven, R. G. (2005). A reciprocal effects model of the causal ordering of self-concept and achievement: New support for the benefits of enhancing self-concept. In H. W. Marsh, R. G. Craven, \& D. M. McInerney (Eds.), International advances in self research: New frontiers for self research (Vol. 2, pp. 17-51). Greenwich, Connecticut: Information Age Publishing.

Muijs, R. D. (1997). Predictors of academic achievement and academic self-concept: A longitudinal perspective. British Journal of Educational Psychology, 67, 263-277.

Osborne, J. W. (1995). Academics, self-esteem, and race: A look at the underlying assumptions of the disidentification hypothesis. Personality and Social Psychology Bulletin, 21, 449-455.

Peixoto, F. (1998). Auto-conceito(s), auto-estima e resultados escolares: A influência da repetência no(s) auto-conceito(s) e na auto-estima de adolescentes [Self-concept(s), self-esteem and school achievement: The influence of retention in adloescents' self-concept(s) and self-esteem]. In M. Alves-Martins (Ed.), Actas do IX Colóquio de Psicologia e Educação (pp. 51-69). Lisboa: I.S.P.A.

Peixoto, F. (2003). Auto-estima, autoconceito e dinâmicas relacionais em contexto escolar [Self-esteem, selfconcept and relational dynamics in school context]. PhD thesis, Universidade do Minho.

Peixoto, F., \& Mata, L. (1993). Efeitos da idade, sexo e nível sócio-cultural no auto-conceito [Effects of age, gender and sócio-cultural level on self-concept]. Análise Psicológica, 11, 401-413.

Peixoto, F., \& Almeida, L. S. (1999). Escala de auto-conceito e auto-estima [Self-concept and self-esteem scale]. In A. P. Soares, S. Araújo, \& S. Caires (Eds.), Avaliação Psicológica: Formas e Contextos (Vol. VI, pp. 632-640). Braga: APPORT.

Peixoto, F., Alves Martins, M., Mata, L., \& Monteiro, V. (1997). Escala de autoconceito para adolescentes de Susan Harter [Harter' scale of self-concept for adolescents]. In M. Gonçalves, I. Ribeiro, S. Araújo, C. Machado, L. Almeida, \& M. Simões (Eds.), Avaliação psicológica: Formas e contextos (Vol. V, pp. 277-284). Braga: APPORT.

Peixoto, F., Alves Martins, Gouveia Pereira, M., Amaral, V., \& Pedro, I. (2001). Os grupos de adolescentes na escola: Percepções intra e inter-grupais [Peer groups of adolescents in school: Perceptions intra and inter-group]. Psicologia-Teoria, Investigação e Prática, 6, 79-93.

Robinson, W. P. (1978). O desinteresse escolar no ensino secundário [Disinvestment in school in secondary school]. Análise Psicológica, 2, 23-32. 
Robinson, W. P., \& Tayler, C. A. (1986). Auto-estima, desinteresse e insucesso escolar em alunos da escola secundária [Self-esteem, disinvestment and school failure in students from secondary school]. Análise Psicológica, 5, 105-113.

Robinson, W. P., \& Tayler, C. A. (1991). Correlates of low academic attainment in three countries: England, France and Japan. Análise Psicológica, 9, 277-290.

Robinson, W. P., \& Breslav, G. (1996). Academic achievement and self-concept of Latvian adolescents in a changed social context. European Journal of Psychology of Education, 11, 399-410.

Robinson, W. P., Tayler, C. A., \& Piolat, M. (1990). School attainment, self-esteem and identity. European Journal of Social Psychology, 20, 1-17.

Senos, J. (1997). Identidade social, auto-estima e Resultados Escolares [Social identity, self-esteem and school achievement]. Análise Psicológica, 15, 123-137.

Senos, J., \& Diniz, T. (1998). Auto-estima, resultados escolares e indisciplina. Estudo exploratório numa amostra de adolescentes [Self-esteem, school achievement and misbehavior. Exploratory study with adolescents]. Análise Psicológica, 16, 267-276.

Skaalvik, E. M., \& Hagtvet, K. A. (1990). Academic achievement and self-concept: An analysis of causal predominance in a developmental perspective. Journal of Personality and Social Psychology, 58, 292-307.

Tajfel, H. (1983). Grupos humanos e categorias sociais [Human groups and social categories]. Lisbon: Livros Horizonte.

Valentine, J. C., \& DuBois, D. L. (2005). Effects of self-beliefs on academic achievement and vice-versa: Separating the chicken from the egg. In H. W. Marsh, R. G. Craven, \& D. M. McInerney (Eds.), International advances in self research: New frontiers for self research (Vol. 2, pp. 52-77). Greenwich, Connecticut: Information Age Publishing.

Veiga, F. H. (1996). Autoconceito e rendimento dos jovens em matemática e ciências: Análise por grupos com diferente valorização do sucesso [Self-concept and achievement of youth in mathematics and sciences: Analysis by groups differing in valuing achievement]. Revista de Educação, 5, 41-53.

Wetherell, M. (1996). Group conflict and the social psychology of racism. In M. Wetherell (Ed.), Identities, groups and social issues (pp. 175-234). London: Sage.

Wichstrøm, L. (1995). Harter's self-perception profile for adolescents: Reliability, validity, and evaluation of the question format. Journal of Personality Assessment, 65, 100-116.

Williams, J. M., \& Currie, C. (2000). Self-esteem and physical development in early adolescence: Pubertal timing and body image. Journal of Early Adolescence, 20, 129-149.

Francisco Peixoto. Instituto Superior de Psicologia Aplicada, R. Jardim do Tabaco, 34, 1149-041, Lisboa, Portugal. E-mail: fpeixoto@ispa.pt

Current themes of research:

Motivation in school context. Self-concept and self-esteem. Family dynamics related to school adjustment.

Most relevant publications in the field of Psychology of Education:

Peixoto, F., \& Carvalho, R. (2009). Parental attitudes toward academic achievement: Effects on motivation, self-concept and school achievement. In M. Wosnitza, S. Karabenick, A. Efklides, \& P. Nenniger (Eds.), Contemporary motivation research: From global to local perspectives (pp. 279-297). Göttingen \& New York: Hogrefe \& Huber.

Pedro, N., \& Peixoto, F. (2006). Satisfação profissional e auto-estima em professores do $2^{\circ}$ e $3^{\circ}$ ciclos do ensino básico. Análise Psicológica, 24, 247-262

Peixoto, F. (2004). What kinds of benefits students have from participate on extracurricular activities?. In $\mathrm{H}$. W. Marsh, J. Baumert, G. E. Richards \& U. Trautwein (Eds.). Self-concept, motivation and identity: Where to from here? Proceedings of the third international biennial SELF research conference. Sydney: SELF Research Centre. (CD-Rom).

Alves Martins, M., Peixoto, F., Gouveia Pereira, M., Amaral, V., \& Pedro, I. (2002). Self-esteem and academic achievement among adolescents. Educational Psychology, 22, 51-62.

Alves Martins, M., \& Peixoto, F. (2000). Self-esteem, social identity and school achievement in adolescence. Psychology: The Journal of the Hellenic Psychological Society, 7, 278-289. 
Leandro S. Almeida. Instituto de Educação e Psicologia, Universidade do Minho, Campus de Gualtar, 4710-057, Braga, Portugal. E-mail: leandro@iep.uminho.pt

\section{Current themes of research:}

Cognition, learning and academic achievement. Transition, adjustment, and academic success at higher education. Psycho-educational assessment.

Most relevant publications in the field of Psychology of Education:

Soares, A. P., Guisande, M. A., Almeida, L. S., \& Páramo, M. F. (2009). Academic achievement in first-year Portuguese college students: The role of academic preparation and learning strategies. International Journal of Psychology, 44(3), 204-212.

Veiga, F., Garcia, F., Neto, F., Almeida, L. (2009). The differentiation and promotion of students' rights in Portugal. School Psychology International, 30(4), 421-436.

Medeiros, T., Peixoto, E., Tavares, J., Ferreira, J., Almeida, L., \& Pacheco, M. (2008). Learning and cognitive development in Portuguese college students. Portuguese Studies Review, 16(1), 1-22.

Almeida, L. S., Miranda, L., Guisande, M. A. (2008). Atribuições causais para o sucesso e fracasso escolares. Estudos de Psicologia, 25(2), 169-176.

Almeida, L. S., Prieto, L. P., Ferrando, M., Oliveira, E., \& Ferrándiz, C. (2008). Torrance test of creative thinking. Thinking Skills and Creativity, 3, 53-58. 